\title{
Music genetics research: Association with musicality of a polymorphism in the AVPR1A gene
}

Luiza Monteavaro Mariath $^{1}$, Alexandre Mauat da Silva ${ }^{1}$, Thayne Woycinck Kowalski ${ }^{1}$, Gustavo Schulz Gattino $^{2}$, Gustavo Andrade de Araujo ${ }^{2}$, Felipe Grahl Figueiredo ${ }^{2}$, Alice Tagliani-Ribeiro ${ }^{1}$, Tatiana Roman ${ }^{1}$, Fernanda Sales Luiz Vianna ${ }^{1}$, Lavínia Schuler-Faccini ${ }^{1}$ and Jaqueline Bohrer Schuch ${ }^{1}$

${ }^{1}$ Programa de Pós-Graduação em Genética e Biologia Molecular, Departamento de Genética, Universidade Federal do Rio Grande do Sul, Porto Alegre, RS, Brazil.

${ }^{2}$ Programa de Pos-Graduação em Saúde da Criança e Adolescente, Faculdade de Medicina, Universidade Federal do Rio Grande do Sul, Porto Alegre, RS, Brazil.

\begin{abstract}
Musicality is defined as a natural tendency, sensibility, knowledge, or talent to create, perceive, and play music. Musical abilities involve a great range of social and cognitive behaviors, which are influenced by both environmental and genetic factors. Although a number of studies have yielded insights into music genetics research, genes and biological pathways related to these traits are not fully understood. Our hypothesis in the current study is that genes associated with different behaviors could also influence the musical phenotype. Our aim was to investigate whether polymorphisms in six genes (AVPR1A, SLC6A4, ITGB3, COMT, DRD2 and DRD4) related to social and cognitive traits are associated with musicality in a sample of children. Musicality was assessed through an individualized music therapy assessment profile (IMTAP) which has been validated in Brazil to measure musical ability. We show here that the RS1 microsatellite of the AVPR1A gene is nominally associated with musicality, corroborating previous results linking AVPR1A with musical activity. This study is one of the first to investigate musicality in a comprehensive way, and it contributes to better understand the genetic basis underlying musical ability.
\end{abstract}

Keywords: musicality; music; vasopressin; AVPR1A.

Received: February 8, 2016; Accepted: December 15, 2016.

\section{Introduction}

The complex behavior of humans is closely influenced by genetic and environmental factors. An increasing number of studies have focused on the biological basis of these characteristics and, currently, many biological pathways and genes involved in different human behaviors are known (Ebstein et al., 2009). Among several factors previously studied, some neuropeptides (e.g., vasopressin) seem to play an important role in affiliative behaviors and social recognition. Serotonergic and dopaminergic neurotransmitter systems are also associated with social cognition and emotional behavior (e.g., anxiety and mood) (Skuse and Gallagher, 2011).

Musicality is described as a natural tendency, sensibility, or talent to create, perceive, and play music. A great range of behavioral, social, and cognitive traits are involved in musical abilities such as playing instruments,

Send correspondence to Lavinia Schuler Faccini. Department of Genetics, Biosciences Institute, Universidade Federal do Rio Grande do Sul, Avenida Bento Gonçalves, 9500, 91501-970, Porto Alegre, RS, Brazil. E-mail: lavinia.faccini@ufrgs.br singing, dancing, arranging music, and improvising (Ukkola et al., 2009). Thus, it is possible that the same factors involved in behavioral traits could also influence musical aptitudes. A number of studies have begun to unveil the genetic basis underpinning musicality, with some promising findings being replicated (see the review by Tan et al., 2014). Despite these recent insights, the genetic basis involved in this trait is not fully understood.

Recently, genomic approaches have been applied to identify genetic loci associated with music skills (see the review by Gingras et al., 2015). Genome-wide linkage and association analyses have pointed several genetic variants which could be segregating with musical aptitude. In particular, a region on chromosome 4q22-23 was identified in two independent linkage-mapping studies in Finnish and Mongolian populations (Pulli et al., 2008; Park et al., 2012; Oikkonen and Jarvela, 2014). Most recently, genome-wide linkage and association scan identified multiple loci containing genes affecting auditory and cognitive functions (Park et al., 2012; Gingras et al., 2015; Oikkonen et al., 2015). These studies suggested that variants in UGT8 (UDP glycosyltransferase 8), GSG1L (Germ Cell-Specific Gene 
1-Like) and $U N C 5 C$ (unc-5 netrin receptor C) genes, might be involved in musical phenotypes (Park et al., 2012; Gingras et al., 2015; Oikkonen et al., 2015). Additionally, copy number variations have been associated with musical abilities, revealing interesting regions involved in neurodevelopment, learning and memory (Ukkola-Vuoti et al., 2013).

In candidate gene association studies, the major findings are related to vasopressin, serotonin and dopamine genes, due to their roles on different behavioral and cognitive traits (Reuter et al., 2006; Donaldson and Young, 2008). Concerning these studies, arginine vasopressin receptor 1A (AVPR1A) and serotonin transporter (SLC6A4) are the main genes associated with musical activities and related behaviors (Bachner-Melman et al., 2005; Granot et al., 2007; Ukkola et al., 2009; Ukkola-Vuoti et al., 2011). Other genes, such as TPH1, COMT, DRD2, DRD5, IGF2, MAOA (Bachner-Melman et al., 2005; Ukkola et al., 2009; Tan et al., 2014) have also been investigated in some of these studies, but the findings were inconclusive.

AVPR1A (12q14-q15) encodes a neuropeptide that is responsible for mediating the influence of the hormone arginine vasopressin (AVP) in the brain. It has an important role in the control of cognitive functions, influencing memory and learning, as well as acting in the modulation of social behavior (Fink et al., 2007). The highly variable microsatellites RS1, RS3, and AVR have been studied extensively in different behavioral traits such as social cognitive behavior (Israel et al., 2008), and autism spectrum disorders (Wassink et al., 2004). Among musical characteristics, these AVPR1A microsatellites have been associated with music memory (Granot et al., 2007), musical perception (Ukkola et al., 2009) and music listening (UkkolaVuoti et al., 2011).

The serotonergic system has been indicated as an important modulator in the control of several behavioral and physiological functions (Coiro et al., 2010). SLC6A4 (17q11.2) codes for the serotonin transporter and is found in the brain, mostly in the cortex and limbic systems, which are both involved with emotions (Ukkola et al., 2009). The 5 -HTTLPR, which is a functional polymorphism located in the promoter region of the gene, influences the rate of serotonin transcription and is associated with different behaviors, including emotional (Zalsman et al., 2006; Cools et al., 2008; Petersen et al., 2012) and musical characteristics such as music memory (Granot et al., 2007) and creative dance performance (Bachner-Melman et al., 2005). Another gene involved with this system is integrin $\beta 3$ (ITGB3). ITGB3 (17q21.32), which encodes a protein involved in neural cellular adhesion and has been characterized as a quantitative trait locus for serotonin levels in blood (Weiss et al., 2004). Some studies have demonstrated that variants in this gene are associated with an increase in serotonin transporter expression and in serotonin uptake (Carneiro et al., 2008; Whyte et al., 2014). These variants have also been related to behavioral disorders (Weiss et al., 2006a; Napolioni et al., 2011; Schuch et al., 2014).

Brain dopamine neurotransmitters are important in the modulation of sensory and motor responses as well as for executive and cognitive functions, and they have been associated with different behavioral traits (Cools and D'Esposito, 2011). Catechol-O-methyltransferase (COMT) is an enzyme that is essential for degrading dopamine in the prefrontal cortical area. It is involved in the regulation of brain dopamine levels. The functional polymorphism Val158Met in the COMT gene (22q11.21) influences the modulation of COMT activity (Wang et al., 2013), and it has been associated with memory, intelligence, and emotional difficulties (Tunbridge et al., 2006; Shaw, 2007).

Five different receptor subtypes mediate dopamine action; however, dopamine receptor D2 (DRD2) and dopamine receptor $\mathrm{D} 4(D R D 4)$ are the most prominent. The $D R D 2$ gene (11q23) is mainly expressed in the striatum and its role is related to several cognitive processes, such as intelligence, learning from errors, and creativity (Reuter et al., 2006; Klein et al., 2007; Shaw, 2007). A functional polymorphism in the promoter region, -141CIns/Del has been associated with alcohol dependence (Lee et al., 2013), schizophrenia (Arinami et al., 1997) and clinical response to antipsychotics (Lencz et al., 2006). The DRD4 gene (11p15.5) is widely expressed in the central nervous system, mainly in regions related to planning and reward, such as the prefrontal cortex, hippocampus, and amygdala (Meador-Woodruff et al., 1996; De La Garza 2nd and Madras, 2000; Simpson et al., 2010). The main polymorphism studied is a 48 bp VNTR in exon 3, which involves nine different alleles; however, the 4-, 2-, and 7- repeat alleles are the most prevalent (Chang et al., 1996). This polymorphism has been associated with attention deficit hyperactivity disorder (Camarena et al., 2007), obsessive compulsive disorder (Walitza et al., 2008), autism spectrum disorders (Faraone et al., 2005), impulsivity (Eisenberg et al., 2007) and prosocial behaviors (Bakermans-Kranenburg and van Ijzendoorn, 2011).

Musical characteristics require social interaction and cognitive processes, presupposing that the core genes related to different behaviors must influence musical phenotypes. We hypothesized that polymorphisms in the six genes mentioned above, which are associated with different social and cognitive behaviors, could also be related to musical traits. Our aim was to investigate the influence of the AVPR1A, SLC6A4, ITGB3, COMT, DRD2, and DRD4 polymorphisms on musicality in a sample of children from Porto Alegre, Brazil, and thus contribute to understanding the genetic basis of musical aptitude. 


\section{Subjects and Methods}

\section{Sample}

Fifty-five students with no musical education from two public schools in Porto Alegre, Brazil, participated in the study. The students were between 7 and 9 years of age and in the 1 st to 4 th grade of elementary school. This study was approved by the Ethics Committee of the Hospital de Clínicas de Porto Alegre (protocol 10-0562), and all of the children's parents received information about the proposal, since they signed an informed consent form.

Interviews, musical assessments, and collection of biological samples were performed by trained music therapists. Children who had listening difficulties or any restriction to sounds or noises were excluded from the study. All participants exhibited typical development.

\section{Musical Assessment}

Musicality was measured through an individualized music therapy assessment profile (IMTAP) (Baxter et al., 2007), which had its Brazilian version validated (da Silva et $a l ., 2013)$. The IMTAP assesses functional abilities for each participant through musical activities performed by trained music therapists. Among 10 behavioral and functional domains that could be evaluated independently, the musicality domain, in particular, was assessed in this study. The musicality domain examines the individuals' innate responses to various musical activities and their ability and desire to participate in each activity. Each IMTAP domain is divided into several sub-domains which help to clearly define the skill sets that are being addressed within the broader domain. The sub-domains of musicality include: fundamentals, tempo, rhythm, dynamics, vocality, perfect and relative pitch, creativity and development of musical ideas, and accompaniment.

IMTAP assessment is done in an objective way. The musicality score of each participant is based in points. The scoring, explained in detail below, is based on the number of times the skills described above are exhibited. All individuals were assessed by the same two music therapists. Although the music therapists were aware that a genetic study would be performed in a posterior step, they had no information on the genetics results. Note that the first objective of IMTAP assessment in our sample was the validation of the instrument in Brazil, excluding any possible biases related to a genetic study.

A structured protocol of musical activities covering all sub-domain abilities was performed for each student. This included three $60 \mathrm{~min}$ sessions which were recorded and further analyzed. For the assessment, sessions were scored according to the consistency with which the student presented the skills covered in the musicality sub-domains. The consistency levels were: $\mathrm{N}=$ Never, $\mathrm{R}=$ Rarely (less than 50\%), I = Inconsistent (50-79\%) and $\mathrm{C}=$ Consistent (80-100\%). Counting the number of opportunities given and dividing by the number of times the skill was exhibited,

A

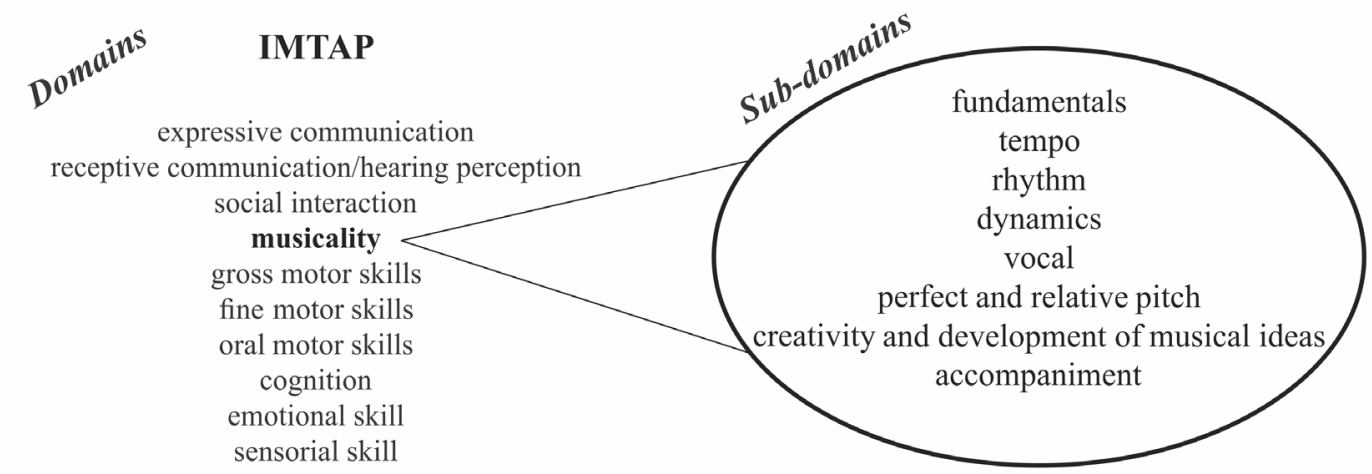

B

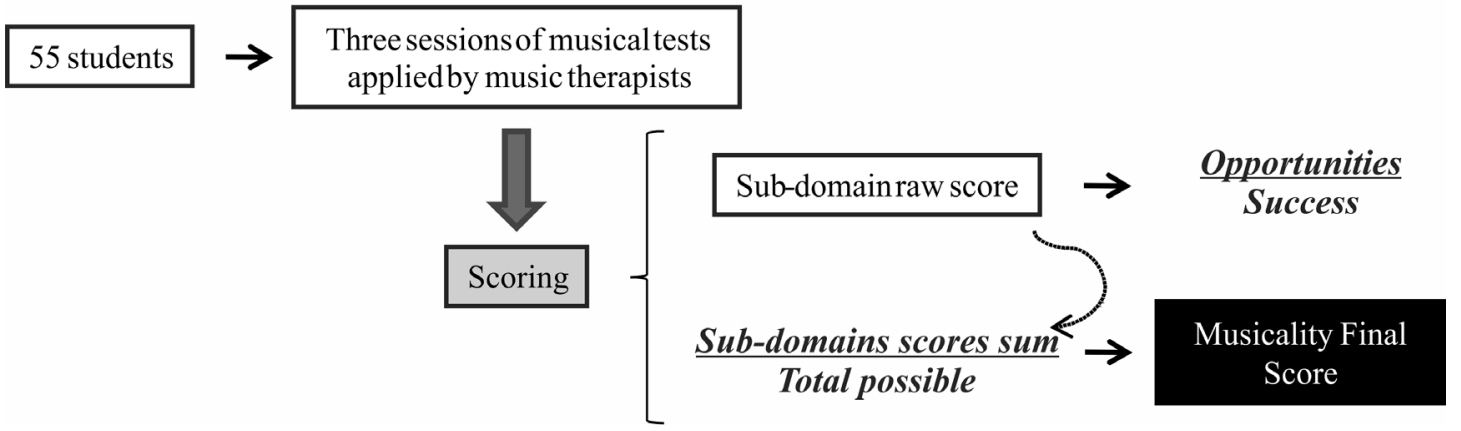

Figure 1 - Representation of IMTAP assessment. (A) The IMTAP evaluates 10 musical and/or behavioral domains. In this study, we analyzed the musicality domain, which is assessed through different sub-domains; (B) the scheme for musicality assessment and scoring used in this study. 
the level of consistency according to this percentage was obtained. Raw scores for sub-domains were calculated based on the number of C, I, R, and $\mathrm{N}$ occurrences in all the activities of each sub-domain. The final score for the domain was calculated by dividing the sum of all sub-domain raw scores by the total possible (Figure 1 shows a representation of the IMTAP assessment). The final score for the domain was calculated by averaging the scores given by the two music therapists, and it is also reported as percentage.

\section{Genotyping}

Saliva samples from all 55 students were collected with the Oragene kit (DNA Genotek, Canada), and DNA extraction was performed in accordance with the manufacturer's protocol.

We genotyped both the highly variable microsatellites RS1 and RS3, which are located in the promoter region, and the AVR microsatellite in the intron of the AVPR1A gene via polymerase chain reaction (PCR), using labeled primers as described in previous studies (Ukkola et al., 2009). PCR products were analyzed using an ABI 3730xl DNA analyzer (Applied Biosystems, USA), and the product sizes were determined using PeakScanner Software v1.0 (Applied Biosystems).

The 5-HTTLPR/rs25531 polymorphism, which is located in the promoter region of the SLC6A4 gene, was analyzed based on the tri-allelic format $\left(\mathrm{S}, \mathrm{L}_{\mathrm{A}}\right.$, and $\mathrm{L}_{\mathrm{G}}$ alleles). PCR and restriction fragment length polymorphism (RFLP) analysis were done in accordance with the techniques previously described by Kaiser et al. (2001) and Stein et al. (2006).

The polymorphisms in the genes ITGB3 and COMT (rs15908 and Val158Met, respectively) were genotyped using the Taqman allelic discrimination method (Applied Biosystems), in accordance with the manufacturer's protocol.

The -141CIns/Del polymorphism in the promoter region of the DRD2 gene was analyzed using the PCR-RFLP method, which was previously described by Arinami et al. (1997). The main DRD4 polymorphism, a 48 bp VNTR in the third exon, was analyzed through PCR, in accordance with Roman et al. (1999).

\section{Statistical Analysis}

Allele frequencies were calculated through gene counting. Arlequin 3.5.1.2 and GenePop 4.2 were used to check the Hardy-Weinberg equilibrium. In order to analyze the influence of each gene polymorphism on musicality, we grouped the students according to their genotypes, based on: allele frequencies, differential expression, and/or previous results, and then compared the musicality scores obtained for each group. For the RS1, RS3, and AVR microsatellites of AVPR1A, we compared carriers of the 4-, 7-, and 5-alleles, respectively, as well as non-carriers. These alleles were selected due to previous literature reports of as- sociations with musical characteristics (Yirmiya et al., 2006; Ukkola et al., 2009; Ukkola-Vuoti et al., 2011). Individuals homozygous for the 5-HTTLPR/rs $25531 \mathrm{~L}_{\mathrm{A}} \mathrm{L}_{\mathrm{A}}$ genotype present a higher SLC6A4 mRNA expression comparing to individuals presenting the other genotypes (Hu et al., 2006). Therefore, we compared $\mathrm{L}_{\mathrm{A}} \mathrm{L}_{\mathrm{A}}$ genotype to the other genotypes ( $\mathrm{SS}, \mathrm{SL}_{\mathrm{G}}, \mathrm{SL}_{\mathrm{A}}, \mathrm{L}_{\mathrm{G}} \mathrm{L}_{\mathrm{G}}$, and $\mathrm{L}_{\mathrm{G}} \mathrm{L}_{\mathrm{A}}$ ). For the rs 15908 variant of the $I T G B 3$ gene we compared C-carriers and non-carriers. The Met allele of Val158Met of the COMT gene has been associated with cognitive processes (Shaw, 2007), therefore we compared Met-carriers and non-carriers. For the $-141 \mathrm{C}$ Ins/Del of the DRD2 gene, students were grouped into Del-carriers and non-carriers, because the Del allele exhibits reduced gene expression (Arinami et al., 1997). The 7-repeat allele (7R) of DRD4 VNTR has been associated with several behavioral traits (Ebstein et al., 1996; Faraone et al., 2001), therefore we compared 7R-carriers and non-carriers among the students.

The association between musicality scores (IMTAP assessment) and the polymorphisms evaluated were analyzed through Generalized Linear Model (GZLM). Normal distribution with identity link function or gamma distribution with log link function were used according to the distribution of musicality scores in each group tested for each polymorphism. All analyses were adjusted for age. Students' age adjustment was performed due to the correlation found ( $\mathrm{r}=0.43, \mathrm{p}=0.001)$ with the musicality scores (Figure S1). Considering multiple testing, a significance threshold corrected by Bonferroni considered 0.05/8 $=0.006$. Statistical analysis was done in SPSS 18.0 for Windows.

\section{Results}

The children's age varied between 84 months (7 years) and 118 months (9 years and 10 months), with a mean of 97.45 months (about 8 years and 1 month). The male:female ratio was $28: 27$. The musicality scores varied between $27.60 \%$ and $76.60 \%$ (mean of $57.12 \%$, standard error of $1.80 \%$ ).

Table 1 shows the allele frequencies of the polymorphisms of the AVPR1A, SLC6A4, ITGB3, COMT, DRD2, and DRD4 genes analyzed in this study. All polymorphisms, except for the RS1 and RS3 microsatellites of AVPR1A, were in Hardy-Weinberg equilibrium.

The results from association analyses between gene polymorphisms and musicality scores are shown in Table 2. We found a nominal association between the RS1 microsatellite of $A V P R 1 A$ and musicality scores. Individuals carrying allele 4 showed higher musicality scores compared to non-carriers $(p=0.038)$ (Table 2$)$. Other polymorphisms evaluated were not associated with musicality scores (Table 2). 
Table 1 - Allele frequency of the polymorphisms analyzed in this study.

\begin{tabular}{|c|c|c|c|}
\hline Gene/polymorphism & Allele & Count & Frequency \\
\hline \multirow[t]{8}{*}{ AVPR1A/ RS1 } & $1(302$ bp) & 1 & 0.0091 \\
\hline & $2(306$ bp) & 10 & 0.0909 \\
\hline & $3(310$ bp) & 55 & 0.5000 \\
\hline & 4 (314 bp) & 31 & 0.2818 \\
\hline & $5(318 \mathrm{bp})$ & 1 & 0.0091 \\
\hline & $6(322 \mathrm{bp})$ & 8 & 0.0727 \\
\hline & 7 (326 bp) & 1 & 0.0091 \\
\hline & $8(330$ bp) & 3 & 0.0273 \\
\hline \multirow[t]{13}{*}{ AVPR1A/ RS3 } & 1 (319 bp) & 2 & 0.0182 \\
\hline & $2(321 \mathrm{bp})$ & 1 & 0.0091 \\
\hline & 3 (323 bp) & 6 & 0.0545 \\
\hline & $4(325$ bp) & 12 & 0.1091 \\
\hline & $5(327 \mathrm{bp})$ & 12 & 0.1091 \\
\hline & $6(329$ bp) & 22 & 0.2000 \\
\hline & 7 (331 bp) & 22 & 0.2000 \\
\hline & 8 (333 bp) & 16 & 0.1455 \\
\hline & $9(335 \mathrm{bp})$ & 3 & 0.0273 \\
\hline & 10 (337 bp) & 4 & 0.0364 \\
\hline & 11 (339 bp) & 5 & 0.0455 \\
\hline & $12(341 \mathrm{bp})$ & 4 & 0.0364 \\
\hline & 14 (310 bp) & 1 & 0.0091 \\
\hline \multirow[t]{6}{*}{ AVPRIA/ AVR } & $3(208$ bp) & 1 & 0.0094 \\
\hline & $4(210$ bp) & 15 & 0.1415 \\
\hline & $5(212$ bp) & 43 & 0.4057 \\
\hline & $6(214$ bp) & 42 & 0.3962 \\
\hline & 7 (216 bp) & 4 & 0.0377 \\
\hline & $8(218$ bp) & 1 & 0.0094 \\
\hline \multirow[t]{3}{*}{ SLC6A4/ 5-HTTLPR } & S & 45 & 0.4091 \\
\hline & $\mathrm{L}_{\mathrm{A}}$ & 52 & 0.4727 \\
\hline & $\mathrm{L}_{\mathrm{G}}$ & 13 & 0.1182 \\
\hline \multirow[t]{2}{*}{$I T G B 3 /$ rs 15908} & A & 66 & 0.6000 \\
\hline & $\mathrm{C}$ & 44 & 0.4000 \\
\hline \multirow[t]{2}{*}{ COMT/ Val158Met } & Val & 63 & 0.5833 \\
\hline & Met & 45 & 0.4167 \\
\hline \multirow[t]{2}{*}{ DRD2/-141CIns/Del } & Ins & 89 & 0.8091 \\
\hline & Del & 21 & 0.1909 \\
\hline \multirow[t]{7}{*}{$D R D 4 /$ VNTR Exon 3} & $2 \mathrm{R}$ & 8 & 0.0727 \\
\hline & $3 \mathrm{R}$ & 3 & 0.0273 \\
\hline & $4 \mathrm{R}$ & 67 & 0.6091 \\
\hline & $5 \mathrm{R}$ & 1 & 0.0091 \\
\hline & $6 \mathrm{R}$ & 4 & 0.0364 \\
\hline & $7 \mathrm{R}$ & 26 & 0.2364 \\
\hline & $8 \mathrm{R}$ & 1 & 0.0091 \\
\hline
\end{tabular}

The allele labels in the RS1, RS3, and AVR microsatellites are in accordance to those used in Yirmiya et al. (2006).

\section{Discussion}

Music has played a central role in human history. It is intrinsic to all cultures, both past and present. Although the origins and adaptive functions of music remain unknown, many authors suggest that human abilities to appreciate and practice music may be a biological adaptation, considering that in a long evolutionary past it may have been essential for survival and reproduction (McDermott and Hauser, 2005; Wang, 2015; Honing et al., 2015). Indeed, evidence for signatures of positive selection for abilities that contribute to musical aptitude has been demonstrated, and a possible shared genetic and evolutionary background between music and language is suggested (Liu et al., 2016). A conceivable reason to explain this positive selection could be the reward value of music, in which increased dopamine secretion would be stimulated during musical activities (Salimpoor et al., 2011; Liu et al., 2016).

All humans inherit an intrinsic form of musicality, in which genetic factors may play an important role in its expression. Therefore, genetic studies of musical abilities will enable us to better understand important questions about the origins and selective pressure of music in human history. Although limited, these studies have emerged in recent years, and with increased research efforts, a clearer understanding of the genetic basis underlying musical abilities may emerge (Tan et al., 2014). In this study, we investigated a possible association between musicality and polymorphisms in the AVPR1A, SLC6A4, ITGB3, COMT, $D R D 2$, and $D R D 4$ genes, which are known to influence behavioral and cognitive functions. We found a nominal association between allele 4 of RS1 microsatellite of AVPR1A gene and higher musicality scores.

The hormone arginine vasopressin (AVP) and its receptor AVPR1A have a key role in controlling cognitive functions such as memory and learning. The AVPR1A gene has been associated with music memory (Granot et al., 2007), music perception (Ukkola et al., 2009), and music listening (Ukkola-Vuoti et al., 2011). Our results add to the evidence of the possible role of $A V P R 1 A$ in influencing music traits. Significant associations between AVPR1A microsatellites and musical characteristics have been reported by different authors (Bachner-Melman et al., 2005; Granot et al., 2007; Ukkola et al., 2009; Ukkola-Vuoti et al., 2011). Since AVPR $1 A$ plays a central role in controlling cognitive functions, modulating social behavior, and influencing memory and learning, these studies strongly suggest a link between different musical activities and human cognitive social skills (Tan et al., 2014). Our results, together with these previous reports, support the idea that $A V P R 1 A$ acting in the neurobiological pathways affecting human social functioning, may modulate important facets of musical traits (Bielsky et al., 2004; Egashira et al., 2007; Ukkola et al., 2009; Tan et al., 2014).

The gene selection for this study was based on previous reports indicating genes associated with musical, be- 
Table 2 - Results of analyses for association between musicality scores and polymorphisms.

\begin{tabular}{|c|c|c|c|c|}
\hline Gene/ polymorphism & Genotype & $\mathrm{N}$ & Musicality score $^{\mathrm{a}}$ & $\mathrm{p}$ \\
\hline$A V P R 1 A$ / RS1 & $4 /-$ & 24 & $60.83(2.38)$ & 0.038 \\
\hline Others $^{\mathrm{b}}$ & 32 & $54.24(2.09)$ & & \\
\hline$A V P R 1 A / \mathrm{RS} 3$ & $7 /-$ & 18 & $61.31(3.19)$ & 0.074 \\
\hline Others $^{\mathrm{c}}$ & 37 & $54.70(1.97)$ & & \\
\hline$A V P R 1 A / \mathrm{AVR}$ & $5 /-$ & 36 & $56.24(2.00)$ & 0.734 \\
\hline Others $^{\mathrm{d}}$ & 18 & $57.45(2.91)$ & & \\
\hline SLC6A4/ 5-HTTLPR & $\mathrm{L}_{\mathrm{A}} \mathrm{L}_{\mathrm{A}}$ & 12 & $57.49(3.48)$ & 0.904 \\
\hline Others $^{\mathrm{e}}$ & 43 & $57.01(1.84)$ & & \\
\hline$I T G B 3 / \mathrm{rs} 15908$ & AA & 18 & $54.04(2.86)$ & 0.250 \\
\hline $\mathrm{C} /-$ & 37 & $58.24(2.13)$ & & \\
\hline$C O M T /$ Val158Met & Val/Val & 17 & $60.39(2.88)$ & 0.193 \\
\hline Met/- & 37 & $55.86(1.95)$ & & \\
\hline DRD2/-141CIns/Del & Ins/Ins & 36 & $57.33(2.13)$ & 0.703 \\
\hline Del/- & 19 & $55.97(2.86)$ & & \\
\hline DRD4/VNTR Exon 3 & $7 \mathrm{R} /-$ & 18 & $57.90(2.57)$ & 0.694 \\
\hline Others ${ }^{\mathrm{f}}$ & 37 & $56.59(2.10)$ & & \\
\hline
\end{tabular}

${ }^{\mathrm{a}}$ Mean (Standard Error); ${ }^{\mathrm{b}}$ All genotypes not containing allele $4 ;{ }^{\mathrm{c}}$ All genotypes not containing allele $7 ;{ }^{\mathrm{d}}$ All genotypes not containing allele $5 ;{ }^{\mathrm{e}}$ Genotypes: SS, SLG, SLA, LGLG, and LGLA; ${ }^{\mathrm{f}}$ All genotypes not containing allele 7R.

havioral, and/or cognitive traits. The SLC6A4 gene has been associated with music memory (Granot et al., 2007) and choral singing (Morley et al., 2012). Other genes, such as COMT, TPH1, DRD2, DRD4, DRD5, IGF2, and MAOA have also been investigated but results have so far been inconclusive. Musical aptitudes comprise a complex network involving a number of genes. These previous studies demonstrating gene associations with musical traits may reflect social communication, emotion, courtship, and other behavioral elements of musical phenotypes (Bachner-Melman et al., 2005; Ukkola et al., 2009). Additionally, AVP and serotonergic and dopaminergic systems share strong functional interactions (Ferris et al., 1997; Seo et al., 2008; Skuse and Gallagher, 2011). Thus, the genes studied here belong to an interactive network involved in several behavioral and cognitive functions. Although some studies have indicated that $S L C 6 A 4$ has a role in musical traits, we failed to demonstrate significant association between this gene and musicality scores. Besides, ITGB3, COMT, DRD2 and $D R D 4$ roles in musical features were also not demonstrated here. Future investigations, using a greater sample size, may demonstrate new insights in which genes are modulating this phenotype.

Most genetic studies of music traits have investigated each musical ability separately (e.g., music memory, music listening, music perception, singing, dance, or others). Thus, there is a need for a more comprehensive investigation of musical abilities, using an approach that includes a broader range of evaluated skills. Given this scenario, we here analyzed musicality in a more complete way, evaluating musical talent in eight domains of musical traits (funda- mentals, tempo, rhythm, dynamics, vocality, perfect and relative pitch, creativity and development of musical ideas, and accompaniment). Nevertheless, musicality is a multifactorial characteristic involving a complex interaction of physical, emotional, cognitive, and psychosocial traits (Levitin, 2012) that challenge its definition and research. Musicality could be investigated in future studies covering other additional features that have not yet been addressed. In addition to the broader characterization of musicality, another singularity in our study was the sample selection. The group studied was quite homogenous, consisting of children that were not attending musical classes, and most of them did not have musical relatives. This differentiates our study from other studies that use either markedly different groups (with and without certain skills) or groups including musical families. Thus, we were able to minimize external influences caused by environmental factors.

The main limitation of our study was the small sample size. However, the musicality assessment was done in a broader manner, using the IMTAP instrument. IMTAP is very extensive. Its use requires a long period of time for musical activities with each participant, for musicality assessment through the analysis of all records, and for subsequent scoring. Therefore, we evaluated a smaller number of children in order to make IMTAP applicable and, consequently, to assess musicality in a unique manner (up until now). Notwithstanding, our sample size may have prevented the detection of small effects, which are related to common genetic variants. Likewise, the statistical power was impaired due to this limitation. 
As mentioned, the genotype distribution for the RS1 and RS3 microsatellites of AVPR1A deviated from the Hardy-Weinberg equilibrium. This observed deviation is most likely attributed to random chance, due to our small sample size and the presence of several rare alleles in these two microsatellites. Studying these highly polymorphic loci in a small sample makes it easier to observe a departure from expected genotype frequencies, such as we did.

Although many studies have addressed music from a biological perspective, discordant points of view could be considered. Some authors described music merely as technology rather than an adaptation, a pleasure-producing substance useless for biological evolution (Pinker, 1997; reviewed in Huron, 2001 and Honing et al., 2015). Notwithstanding, recent studies have highlighted different genetic variants involved in musical skills, suggesting the important contribution of biology in this behavior. Although the elucidation of a genetic basis underlying musical characteristics is very challenging due to the multifactorial features, a number of studies have yielded important insights. Replication of these results in different studies is required to confirm the findings. In view of the great complexity of factors influencing musical aptitudes, we propose that our suggestive results for the AVPR1A gene point to the communicative and social behavioral facets of musical abilities.

In conclusion, our results indicate a contribution from the RS1 polymorphism of the AVPR1A gene towards obtaining higher musicality scores. This study is one of the first to investigate musicality in a comprehensive way, evaluating a number of musical aptitudes jointly. We provided an additional investigation on genetic factors influencing musical traits and we expect to contribute to a deeper understanding of the complex role of genes influencing this phenotype.

\section{Acknowledgments}

We would like to thank the children and their parents and teachers for participating. This work was funded by the Brazilian Research Council (CNPq, process nr. 400554/2012-7) and Coordination of Superior Level Staff Improvement (CAPES).

\section{References}

Arinami T, Gao M, Hamaguchi H and Toru M (1997) A functional polymorphism in the promoter region of the dopamine D2 receptor gene is associated with schizophrenia. Hum Mol Genet 6:577-582.

Bachner-Melman R, Dina C, Zohar AH, Constantini N, Lerer E, Hoch S, Sella S, Nemanov L, Gritsenko I, Lichtenberg P, et al. (2005) AVPR1a and SLC6A4 gene polymorphisms are associated with creative dance performance. PLoS Genet 1:e42.

Bakermans-Kranenburg MJ and van Ijzendoorn MH (2011) Differential susceptibility to rearing environment depending on dopamine-related genes: New evidence and a meta-analysis. Dev Psychopathol 23:39-52.

Baxter HT, Berghofer JA, MacEwan L, Nelson J, Peters K and Roberts P (2007) The Individualized Musical Assessment Profile: IMTAP. Jessica Kingsley Publishers, London and Philadelphia, $196 \mathrm{p}$.

Bielsky IF, Hu SB, Szegda KL, Westphal H and Young LJ (2004). Profound impairment in social recognition and reduction in anxiety-like behavior in vasopressin V1a receptor knockout mice. Neuropsychopharmacology 29:483-493.

Camarena B, Loyzaga C, Aguilar A, Weissbecker K and Nicolini H (2007) Association study between the dopamine receptor D(4) gene and obsessive-compulsive disorder. Eur Neuropsychopharmacol 17:406-409.

Carneiro AM, Cook EH, Murphy DL and Blakely RD (2008) Interactions between integrin $\alpha \operatorname{IIb} \beta 3$ and the serotonin transporter regulate serotonin transport and platelet aggregation in mice and humans. J Clin Invest 118:1544-1552.

Chang FM, Kidd JR, Livak KJ, Pakstis AJ and Kidd KK (1996) The world-wide distribution of allele frequencies at the human dopamine D4 receptor locus. Hum Genet 98:91-101.

Coiro V, Maffei ML, Volta E, Cataldo S, Minelli R, Vacca P, Volpi R and Chiodera P (2010) Effect of serotonergic system on AVP secretion induced by physical exercise. Neuropeptides 44:53-6.

Cools R and D'Esposito M (2011) Inverted-U-shaped dopamine actions on human working memory and cognitive control. Biol Psychiatry 69:e113-25.

Cools R, Roberts AC and Robbins TW (2008) Serotoninergic regulation of emotional and behavioural control processes. Trends Cogn Sci 12:31-40.

da Silva AM, Gattino GS, de Araujo GA, Mariath LM, Riesgo RS and Schuler-Faccini L (2013) Translation to Brazilian Portuguese language and validation of the Individualized Music Therapy Assessment Profile (IMTAP) scale for use in Brazil. Rev Bras Musicoter 14:67-80.

De La Garza 2nd R and Madras BK (2000) [(3)H]PNU-101958, a $\mathrm{D}(4)$ dopamine receptor probe, accumulates in prefrontal cortex and hippocampus of non-human primate brain Synapse 37:232-244.

Donaldson ZR and Young LJ (2008) Oxytocin, vasopressin, and the neurogenetics of sociality. Science 322:900-904.

Ebstein RP, Novick O, Umansky R, Priel B, Osher Y, Blaine D, Bennett ER, Nemanov L, Katz M and Belmaker RH (1996) Dopamine D4 receptor (D4DR) exon III polymorphism associated with the human personality trait of novelty seeking. Nat Genet 12:78-80.

Ebstein RP, Israel S, Lerer E, Uzefovsky F, Shalev I, Gritsenko I, Riebold M, Salomon S and Yirmiya N (2009) Arginine vasopressin and oxytocin modulate human social behavior. Ann N Y Acad Sci 1167:87-102.

Egashira N, Tanoue A, Matsuda T, Koushi E, Harada S, Takano Y, Tsujimoto G, Mishima K, Iwasaki K and Fujiwara M (2007) Impaired social interaction and reduced anxietyrelated behavior in vasopressin V1a receptor knockout mice. Behav Brain Res 178:123-127.

Eisenberg DT, Mackillop J, Modi M, Beauchemin J, Dang D, Lisman SA, Lum JK and Wilson DS (2007) Examining impulsivity as an endophenotype using a behavioral approach: A DRD2 TaqI A and DRD4 48-bp VNTR association study. Behav Brain Funct 3:2. 
Faraone SV, Doyle AE, Mick E and Biederman J (2001) Metaanalysis of the association between the 7-repeat allele of the dopamine $\mathrm{D}(4)$ receptor gene and attention deficit hyperactivity disorder. Am J Psychiatry 158:1052-1057.

Faraone SV, Perlis RH, Doyle AE, Smoller JW, Goralnick JJ, Holmgren MA and Sklar P (2005). Molecular genetics of attention-deficit/hyperactivity disorder. Biol Psychiatry 57:1313-1323.

Ferris CF, Melloni Jr RH, Koppel G, Perry KW, Fuller RW and Delville Y (1997). Vasopressin/serotonin interactions in the anterior hypothalamus control aggressive behavior in golden hamsters. J Neurosci 17:4331-4340.

Fink S, Excoffier L and Heckel G (2007). High variability and non-neutral evolution of the mammalian avprla gene. BMC Evol Biol 7:176.

Honing H, ten Cate C, Peretz I and Trehub SE (2015) Without it no music: Cognition, biology and evolution of musicality. Phil Trans R Soc B 370:20140088.

Huron D (2001) Is music an evolutionary adaptation? Ann NY Acad Sci 930:43-61.

Gingras B, Honing H, Peretz I, Trainor LJ and Fisher SE (2015) Defining the biological bases of individual differences in musicality. Phil Trans R Soc B 370:20140092.

Granot R, Frankel Y, Gritsenko V, Lerer E, Gritsenko I, BachnerMelman R, Israel S and Ebstein RP (2007) Provisional evidence that the arginine vasopressin 1a receptor gene is associated with musical memory. Evol Hum Behav 28:313-318.

Hu XZ, Lipsky RH, Zhu G, Akhtar LA, Taubman J, Greenberg $\mathrm{BD}, \mathrm{Xu} \mathrm{K}$, Arnold PD, Richter MA, Kennedy JL, et al. (2006) Serotonin transporter promoter gain-of-function genotypes are linked to obsessive-compulsive disorder. Am J Hum Genet 78:815-826.

Israel S, Lerer E, Shalev I, Uzefovsky F, Reibold M, BachnerMelman R, Granot R, Bornstein G, Knafo A, Yirmiya N, et al. (2008) Molecular genetic studies of the arginine vasopressin 1a receptor (AVPR1a) and the oxytocin receptor (OXTR) in human behaviour: From autism to altruism with some notes in between. Prog Brain Res 170:435-449.

Kaiser R, Tremblay PB, Schmider J, Henneken M, Dettling M, Muller-Oerlinghausen B, Uebelhack R, Roots I and Brockmöller J (2001) Serotonin transporter polymorphisms: No association with response to antipsychotic treatment, but associations with the schizoparanoid and residual subtypes of schizophrenia. Mol Psychiatry 6:179-185.

Klein TA, Neumann J, Reuter M, Hennig J, von Cramon DY and Ullsperger M (2007) Genetically determined differences in learning from errors. Science 318:1642-1645.

Lee SH, Lee BH, Lee JS, Chai YG, Choi MR, Han DM, Ji H, Jang GH, Shin HE and Choi IG (2013) The association of DRD2 -141C and ANKK1 TaqIA polymorphisms with alcohol dependence in Korean population classified by the Lesch typology. Alcohol Alcoholism 48:426-432.

Lencz T, Robinson DG, Xu K, Ekholm J, Sevy S, Gunduz-Bruce H, Woerner MG, Kane JM, Goldman D and Malhotra AK (2006) DRD2 promoter region variation as a predictor of sustained response to antipsychotic medication in first-episode schizophrenia patients. Am J Psychiatry 163:529-531.

Levitin DJ (2012) What does it mean to be musical? Neuron 73:633-637.

Liu X, Kanduri C, Oikkonen J, Karma K, Raijas P, Ukkola-Vuoti L, Teo Y and Jarvela I (2016) Detecting signatures of posi- tive selection associated with musical aptitude in the human genome. Sci Rep 6:21198.

McDermott J and Hauser M (2005) The origins of music: Innateness, uniqueness, and evolution. Music Perception 23:2959.

Meador-Woodruff JH, Damask SP, Wang J, Haroutunian V, Davis KL and Watson SJ (1996) Dopamine receptor mRNA expression in human striatum and neocortex. Neuropsychopharmacology 15:17-29.

Morley AP, Narayanan M, Mines R, Molokhia A, Baxter S, Craig G, Lewis CM and Craig I (2012) AVPR1A and SLC6A4 polymorphisms in choral singers and non-musicians: A gene association study. PLoS One 7:e31763.

Napolioni V, Lombardi F, Sacco R, Curatolo P, Manzi B, Alessandrelli R, Militerni R, Bravaccio C, Lenti C, Saccani M, et al. (2011) Family-based association study of ITGB3 in autism spectrum disorder and its endophenotypes. Eur J Hum Genet 19:353-359.

Oikkonen J and Jarvela I (2014) Genomics approaches to study musical aptitude. Bioessays 36:1102-1108.

Oikkonen J, Huang Y, Onkamo P, Ukkola-Vuoti L, Raijas P, Karma K, Vieland VJ and Jarvela I (2015) A genome-wide linkage and association study of musical aptitude identifies loci containing genes related to inner ear development and neurocognitive functions. Mol Psychiatry 20:275-282.

Park H, Lee S, Kim HJ, Ju YS, Shin JY, Hong D, von Grotthuss M, Lee DS, Park C, Kim JH, et al. (2012) Comprehensive genomic analyses associate UGT8 variants with musical ability in a Mongolian population. J Med Genet 49:747-752.

Petersen IT, Bates JE, Goodnight JA, Dodge KA, Lansford JE, Pettit GS, Latendresse SJ and Dick DM (2012) Interaction between serotonin transporter polymorphism (5-HTTLPR) and stressful life events in adolescents' trajectories of anxious/depressed symptoms. Dev Psychol 48:1463-1475.

Pinker S (1997) How the Mind Works. Norton, New York, 660 p.

Pulli K, Karma K, Norio R, Sistonen P, Goring HHH and Jarvela I (2008) Genome-wide linkage scan for loci of musical aptitude in Finnish families: Evidence for a major locus at 4q22. J Med Genet 45:451-456.

Reuter M, Roth S, Holve K and Hennig J (2006) Identification of first candidate genes for creativity: A pilot study. Brain Res 1069:190-197.

Roman T, Bau CH, Almeida S and Hutz MH (1999) Lack of association of the dopamine D4 receptor gene polymorphism with alcoholism in a Brazilian population. Addict Biol 4:203-207.

Salimpoor VN, Benovoy M, Larcher K, Dagher A and Zatorre RJ (2011) Anatomically distinct dopamine release during anticipation and experience of peak emotion to music. Nat Neurosci 14:257-262.

Schuch JB, Muller D, Endres RG, Bosa CA, Longo D, SchulerFaccini L, Ranzan J, Becker MM, dos Santos Riesgo R and Roman T (2014) The role of beta3 integrin gene variants in Autism Spectrum Disorders - diagnosis and symptomatology. Gene 553:24-30.

Seo D, Patrick CJ and Kennealy PJ (2008) Role of serotonin and dopamine system interactions in the neurobiology of impulsive aggression and its comorbidity with other clinical disorders. Aggress Violent Behav 13:383-395.

Shaw P (2007) Intelligence and the developing human brain. Bioessays 29:962-973. 
Simpson J, Vetuz G, Wilson M, Brookes KJ and Kent L (2010) The DRD4 receptor Exon 3 VNTR and 5' SNP variants and mRNA expression in human post-mortem brain tissue. Am J Med Genet B Neuropsychiatr Genet 153b:1228-1233.

Skuse DH and Gallagher L (2011) Genetic influences on social cognition. Pediatr Res 69:85r-91r.

Stein MB, Seedat S and Gelernter J (2006) Serotonin transporter gene promoter polymorphism predicts SSRI response in generalized social anxiety disorder. Psychopharmacology (Berl) 187:68-72.

Tan YT, McPherson GE, Peretz I, Berkovic SF and Wilson SJ (2014) The genetic basis of music ability. Front Psychol 5:658.

Tunbridge EM, Harrison PJ and Weinberger DR (2006) Catechol-o-methyltransferase, cognition and psychosis: Val158Met and beyond. Biol Psychiatry 60:141-151.

Ukkola LT, Onkamo P, Raijas P, Karma K and Järvelä I (2009) Musical aptitude is associated with AVPR1A-haplotypes. PLoS One 4:e5534.

Ukkola-Vuoti L, Oikkonen J, Onkamo P, Karma K, Raijas P and Jarvela I (2011) Association of the arginine vasopressin receptor 1A (AVPR1A) haplotypes with listening to music. J Hum Genet 56:324-329.

Ukkola-Vuoti L, Kanduri C, Oikkonen J, Buck G, Blancher C, Raijas P, Karma K, Lahdesmaki H and Jarvela I (2013) Genome-wide copy number variation analysis in extended families and unrelated individuals characterized for musical aptitude and creativity in music. PLoS ONE 8:e56356.

Walitza S, Scherag A, Renner TJ, Hinney A, Remschmidt H, Herpertz-Dahlmann B, Schulz E, Schafer H, Lange KW, Wewetzer C, et al. (2008) Transmission disequilibrium studies in early onset of obsessive-compulsive disorder for polymorphisms in genes of the dopaminergic system. J Neural Transm 115:1071-1078.

Wang T (2015) A hypothesis on the biological origins and social evolution of music and dance. Front Neurosci 9:30.

Wang Y, Li J, Chen C, Zhu B, Moysis RK, Lei X, Li H, Liu Q, Xiu $\mathrm{D}$, Liu B, et al. (2013) COMT rs4680 Met is not always the 'smart allele': Val allele is associated with better working memory and larger hippocampal volume in healthy Chinese. Genes Brain Behav 12:323-329.

Wassink TH, Piven J, Vieland VJ, Pietila J, Goedken RJ, Folstein SE and Sheffield VC (2004) Examination of AVPR1a as an autism susceptibility gene. Mol Psychiatry 9:968-972.

Weiss LA, Kosova G, Delahanty RJ, Jiang L, Cook EH, Ober C and Sutcliffe JS (2006a) Variation in ITGB3 is associated with whole-blood serotonin level and autism susceptibility Eur J Hum Genet 14:923-931.

Weiss LA, Veenstra-Vanderweele J, Newman DL, Kim SJ, Dytch $\mathrm{H}$, McPeek MS, Cheng S, Ober C, Cook Jr EH and Abney M (2004) Genome-wide association study identifies ITGB3 as a QTL for whole blood serotonin. Eur J Hum Genet 12:949954.

Whyte A, Jessen T, Varney S and Carneiro AM (2014) Serotonin transporter and integrin beta 3 genes interact to modulate serotonin uptake in mouse brain. Neurochem Int 73:122-126.

Yirmiya N, Rosenberg C, Levi S, Salomon S, Shulman C, Nemanov L, Dina C and Ebstein RP (2006) Association between the arginine vasopressin 1a receptor (AVPR1a) gene and autism in a family-based study: Mediation by socialization skills. Mol Psychiatry 11:488-494.

Zalsman G, Huang YY, Oquendo MA, Burke AK, Hu XZ, Brent DA, Ellis SP, Goldman D and Mann JJ (2006) Association of a triallelic serotonin transporter gene promoter region (5-HTTLPR) polymorphism with stressful life events and severity of depression. Am J Psychiatry 163:1588-1593.

\section{Supplementary Material}

The following online material is available for this article: Figure S1 - Correlation between students' age and musicality scores

Associate Editor: Maria Luiza Petzl-Erler

License information: This is an open-access article distributed under the terms of the Creative Commons Attribution License (type CC-BY), which permits unrestricted use, distribution and reproduction in any medium, provided the original article is properly cited. 